\title{
KOMMENTAR
}

\section{POLITIVOLDSAKEN I BERGEN \\ - DET ENDELIGE UTFALL}

\section{AV PROFESSOR DR.JUR. ANDERS BRATHOLM}

Saken - på det trinn den da befant seg - ble grundig omtalt av professor Kjell Inge Bjørvik i NTfK 1990 s. 13-29: "Boomerangsakene i Bergen. En serie rettsskandaler og bakgrunnen for dem." I sin innledning skrev bl.a. Bjørvik:

"Rettsapparatets behandling av boomerangsakene og andre saker som er relatert til Gunnar Nordhus og Edvard Vogts voldsprosJekt, vil for all fremtid bli stående som en skamplett på rettsstaten Norge. En rekke grunnleggende rettssikkerlietsgarantier er brutt, og $\mathrm{i}$ en grad som gjør det berettiget å påstå at rettsapparatet i realiteten er satt ut av funksjon når det gjelder boomerangsakene og andre saker som er relatert til Nordhus og Vogts voldsprosjekt."

Dette er sterke ord. Den senere utvikling i saken viser at Bjørvik har dekning for sin karakteristikk. Jeg må - når det gjelder dokumentasjonen, vise til min sluttbok om saken: "Politi, påtalemyndighet, presse og rettssikkerhet. Politivoldsaken i Bergen - foran og bak kulissene" (1999).

På denne bakgrunn er det forunderlig at en norsk førstestatsadvokat, Morten Eriksen, kunne skrive i NTfK i 2002: "Etter 19 år med forskning, granskningskommisjoner, etterforskning og debatt er det ikke lett å peke ut noen 'vinnere' i debatten, bare mange tapere" (s.49).

I et svar i tidsskriftet, samme årgang s. 136-139, forsøkte jeg å gi et mer dekkende perspektiv på saken. Jeg nevnte bl.a. at de syv av voldsforskernes informanter som ble straffedømt for å ha gitt "falsk forklaring" om politivold, alle var blitt frifunnet etter å ha fått gjenopptatt straffesakene. De ble for øvrig til sammen tilkjent 2,4 mill. kr. i erstatning/oppreisning for å ha sonet straff for forhold de senere ble frifunnet for.

Jeg pekte i min svarartikkel på at utfallet av saken hadde vært en seier også for forskerne Nordhus/Vogt og for de som gransket saken, og ikke minst for rettssikkerheten og forsknings-/ ytringsfriheten.

Etter at dette ble skrevet har Nordhus/Vogt opplevd en ny seier:

Den erstatningssaken som de anla mot staten på grunn av trakasseringen de opplevde fra Bergen-politiets og påtalemyndighetens side, endte i september 2002 med forlik.

Som et ledd i forliket ble de to forskerne samlet tilkjent om lag to mill. kr. i oppreisning for den uretten de hadde vært offer for. Samtidig utferdiget staten ved Justisdepartementet en erklæring, hvor det ble gitt uttrykk for en beklagelse for den overlast de hadde lidt. De fikk ros for sin forskningsinnsats, og det ble fremhevet at ulovlig voldsbruk fra politiets side måtte unngås, og at den måtte avdekkes når den forekom. "Nordhus og Vogts arbeid må ses i dette perspektiv", heter det til slutt.

Jeg tror det er dekning for å hevde at ytrings- og forskningsfriheten ikke har vært utsatt for mer alvorlige krenkelser etter krigen og okkupasjonen enn i dette tilfellet. 